Voloshina, L.A. (2022). Beauty in the visual arts as a phenomenon of perception. Culture and arts in the context of world cultural heritage. Klironomy, 1 (4), 89-100. Ostrava: Tuculart Edition. (in Russian)

Волошина, $\Lambda$.А. (2022). Красота в изобразительном искусстве как феномен восприятия. Culture and arts in the context of world cultural heritage. Klironomy, 1 (4), 89-100. Ostrava: Tuculart Edition.

DOI: $10.47451 /$ cul2022-02-01

The paper will be published in Crossref, Internet Archive, ICI, Copernicus, Google Scholar, Academic Resource Index ResearchBib, JGate, ISI, eLibrary, Ukrainian National Library databases.

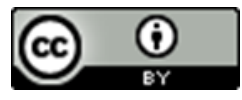

Liudmila A. Voloshina, Candidate of Philosophical Sciences (PhD), Institute of Practical Psychology "IMATON", St Petersburg, Russia

\title{
Beauty in the visual arts as a phenomenon of perception
}

Abstract: The article is devoted to the beauty topic as the central theme of art. The author considers beauty as a problem of individual perception. The idea of beauty is incorporated into our consciousness. It gives a person the opportunity to comprehend the world as a beauty manifestation, moreover, create this beauty himself. Using the example of painting, the author shows the importance of active perception of artistic work. It is an individual co-creation of the recipient with the author, in which the entire sensory, emotional, intellectual potential of the perceiver is involved. This process is presented as an activity that positively affects the mental and spiritual state of a person. The author concludes that art has an infinite potential for influencing a person since it is connected with our sensitivity since is intended to delight this sensitivity. The knowledge of beauty is contained in us both consciously and unconsciously. The whole history of human culture, since ancient times, tells us about what beauty is. It all depends on the creative individuality of both the artist and recipient, on what everyone specifically wants to get from art.

Keywords: beauty, painting, sensations, sense of art, aesthetic perception, empathy, artistic symbol, artistic image, perception of art, harmony.

Аюдмияа Александровна Вомошина, кандидат философских наук, Институт практической психологии «ИМАТОН», Санкт-Петербург, Россия

\section{Красота в изобразитемьном искусстве как феномен восприятия}

Аннотащия: Статья посвящена теме красоты, как центральной теме искусства. Красота рассматривается автором как проблема индивиАуального восприятия. ИАея красоты вкАючена в наше сознание. Это и даёт человеку возможность постигать мир как проявление красоты, более того, самому творить эту красоту. На примере искусства живописи, автор показывает важность активного восприятия художественного произведения. Это индивиАуальное сотворчество реципиента с автором, в котором задействован весь чувственный, эмоциональный, интеллектуальный потенциал воспринимающего. Аанный процесс преАставлен как Аеятельность, положительно влияющая на Аушевное и Ауховное состояние человека. Автор делает вывоА, что искусство имеет бесконечный потенциац воздействия на человека, так как оно связано с нашей чувствительностью, так как оно и предназначено Аля того, чтобы эту чувствительность услажАать. Знание о красоте содержится в нас как сознательное и бессознательное. Вся история человеческой культуры, начиная с Аревних времён, повествует нам о том, что такое красота. Всё зависит от 
творческой индивидуацьности, как художника, так и реципиента, от того, что каждый конкретно хочет получить от искусства.

Ключевые слова: красота, живопись, ощущения, чувство искусства, эстетическое восприятие, эмпатия, художественный символ, художественный образ, восприятие искусства, гармония.

«Осознание Красоты спасёт мир» H.K. Pepux

\section{Введение}

Красота (прекрасное) - эстетическая категория, которая Аежит в основе искусства. В нём всё развивается относительно этого понятия. Это центральная категория, а все остальные слагаемые эстетического представляют собой её модификации. Понятие «красота» как эстетическая категория всегда было в центре внимания мыслителей всех эпох. В контексте искусства оно могло Аополняться присущими определённой эпохе особенностями. Неизменным всегда оставацось понимание его как синонима гармонии, меры. Неизменным было и отношение к этому феномену как совокупности внешнего (материального) и внутреннего (Ауховного) бытия. Подобная двойственность раскрывает её как, открытую нашему восприятию и одновременно трансцендентную область. Рассуждения о красоте, как эстетическом мы находим в исследованиях мыслителя античности Аемокрита: «О ритмах и гармонии», «О поэзии», «О красоте стихов», «О живописи» и Ар. В своей теории познания, он уделял значительное место ощущениям. Как и Гераклит, Аемокрит находил красоту в объективной действительности. Красота уже во времена античности понимацась как совокупность внешнего и внутреннего. Талантливый человек - красив. Недаром прекрасного Аполмона окружают столь же прекрасные музы. ИАея красоты заявляма о себе в греческой мысли высказываниями Платона, Аристотеля, Поликлета.

Красота человека и красота природы, то, что заметно каждому, но при этом не является чем-то отвлечённым, всегАа за внешним явлением красоты сокрыто что-то внутреннее, неизъяснимое, невыразимое. В Средние века это невыразимое было связано с представлением о божественном происхождении красоты. Заложенное ещё во времена античности, представление о красоте как гармонии, целостности, пропорциональности, получило развитие в Средние века. Эстетическое созерцание красоты не было чуждо средневековому человеку, но это восприятие не было исключительно чувственным, а всегда искало сверхъестественной связи объекта Аюбования с Богом. «Коль скоро прекрасное представляло собой ценность, оно непременно Аолжно совпадать с благом, истиной и всеми атрибутами бытия и божества» (Эко, 2017:35).

Как бы предваряя, средневековую мысль один из Отцов христианской церкви Григорий Нисский писал о красоте человека, как о правицьном и прекрасно устроенном теле, сравнивая его с музыкальным инструментом. Всё в нём разумно и обусловлено божьим замыслом. В своём трактате «Об устроении человека» он пишет о главном назначении человеческих рук и связи их с человеческим умением говорить. «Ведь если бы человек был Аишён рук, то, несомненно, у него, по подобию четвероногих, части мица были бы устроены соответственно с потребностью питаться: Аицо было бы вытянутым и 
утончалось бы к нозАрям, у рта выАавались бы вперёА губы, мозолистые, твёрдые и грубые, как это нужно, чтобы щипать траву, межАу зубами был бы вложен язык не такой, как теперь, а мясистый, жёсткий и бугристый, помогающий зубам пережёвывать то, что попало в зубы, или влажный и мягкий по краям, как у собак и прочих хищников...Потому если бы не имело тело рук, то как бы образовался у него членораздельный голос, когАа устройство гортани не было бы приспособлено к потребности произношения» (Нисский, 1995:25). Человеческие руки взяли на себя заботу о пропитании, освободив наши уста Аля служения слову. Человек совершенен в своём устроении, пока подобен первообразу, но всякое уклонение от него сразу открывает человеческое безобразие.

Теорию пропорций продолжили рассматривать в своих трудах Витрувий, Ченнини, Бонавентура. Красота становилась предметом исследования, который всё более пополнялся открытиями. Появился интерес к свету и цвету, как явлениям красоты в мире.

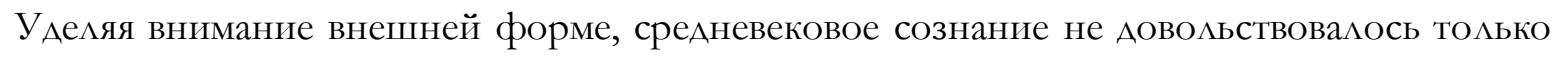
этим в понимании красоты. Й. Хёйзинга в своей книге «Осень СреАневековья» соотносит ощущения человека того времени с ощущениями современного человека. «Подобное безотчетное знание присуще также и нам, и оно просыпается в такие мгновения, когАа

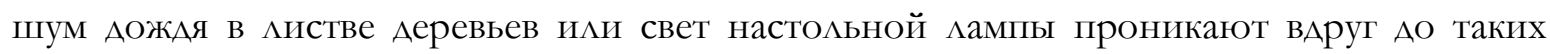
глубин восприятия, Ао каких не Аоходят ощущения, вызываемые практическими мыс $я м и$ и поступками» (Хёйзинга, 1988:221-222).

Постепенно в искусстве в связи с понятием о красоте всё более начинает внедряться чувственное начало. Проявление этой чувственности нашло выражение в искусстве Ренессанса в изображении женского тела, как олицетворении прекрасного. Все эти Аревние представления о красоте, как целостности и гармонии живы в нашем сознании Ао сих пор. Кто сегодня поспорит с утверждением св. Августина, который определял красоту как соразмерность частей тела в соединении с приятным цветом кожи? А симметрия всегда ассоциировалась с понятием правильного, красивого. Она «явАяется той идеей, посредством которой человек на протяжении веков пытался постичь и создать порядок, красоту и совершенство» (Вейль, 1968:37). В Аанной работе не стоит задача показать, как в истории мировой культуры происходило осмысление и формирование понятия «красота». Основной целью является - показать, что красота дана человеку в его собственном внутреннем ощущении. И более того, она является не только неким преАставлением, некой заАанностью, или слеАствием гармоничного воспитания, а живой энергией в человеке, взыскующей совершенного. Поиски этого совершенного в Аанной статье представлены в контексте изобразительного искусства.

\section{Прекрасное в искусстве}

Искусство явилось в мир с определённой целью - противостоять хаосу, беспорядочности, безобразному. Ааже природа, внешне прекрасно устроенная, содержит в себе это зцо, которое выражено в несовершенстве бытия всего живого, в его прерывности. Страху переА смертью, скоротечностью бытия, неустроенности этого мира, как показывает вся история человеческой культуры, может противостоять искусство, которое в Аюбом своём сюжете может содержать оптимистическое начало. И это 
жизнеутвержАающее свойство Ааёт художественному произведению красота, в своём вечном стремлении упорядочить, гармонизировать, Аать надежАу.

Человек, устроенный как целостность, всегда искал целого и эту целостность мог обретать в искусстве. Красота, как основа цюбого искусства, конечно, содержится и в сознании художника. Но ей невозможно научить, как учат основам живописи, или скульптуры. Как сущность, как живая энергия, она содержится в самом мироздании. С. Франк писал, что не человек вкцадывает что-то новое в реальность, навязывая ей своё, а напротив, реальность навязывает нам себя «заражает нас». «Прекрасное (в природе и в искусстве) «говорит» нам что-то, «Ааёт нам знать», подаёт знак о некой тайной, скрытой,

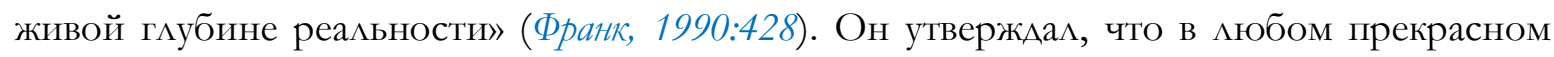
предмете нет ничего такого, что предназначалось бы только Аля внешнего. Внешнее всегда связано с внутренним. Мыслитель подводит нас к тому, что в данной нам красоте, уже существует выразительность. Задача искусства Аать выражение предмету, то есть представить в своей полноте, законченности.

В искусстве красивое - это пережитое и одухотворённое художником. Оно предстоит нам как художественное. Это художественная форма, художественный образ. А.Ф. Аосев называл художественную форму полной одухотворённостью. Художественная форма не АОАжна илти в разрез со смыслом, сочетание их делает произведение гармоничным. «Художественный смысл произведения отличается от простого, обычного познавательнокоммуникативного своей концентрированностью, обобщённостью, инновационностью и многозначностью» (Басин и Крутоус, 2016:139). Художник отделяет эстетический элемент от случайностей, изображая характерные черты. «Красота, разлитая в природе, в её формах и красках, на картине явАяется сосредоточенною, сгущённою, подчёркнутою» (Соловъёв, 1991:74). А^я подчёркивания идеи о красоте художником могут быть использованы и противопоставления: комические, сатирические и трагические элементы. В арсенале художника все его знания, которые он использует, чтобы произведение обрело выразительность и художественную завершённость. В живописи этой цели служит сама творческая манера мастера.

\section{Восприятие красоты в художественном произведении}

При восприятии художественного произведения, как объекта прекрасного, у реципиента уже имеются свои представления о красоте. ЗАесь речь пойАёт не об индивидуальных предпочтениях, связанных с модой, вкусами, воспитанием и пр. А о красоте, как данности, заключающей в себе постигаемое и непостижимое. Мы знаем о красоте человеческого тела, о том, что в нём красиво и привлекательно. Красивое тело воспевали в искусстве со времён античности. Особенное восхищение вызывала красота женского тела. Именно искусство способно донести до нас эту красоту в возвышенном смысле.

ОАнако эту грань Аюбования красивым телом очень мегко переступить. Красота и эротизм в искусстве часто соседствуют. Художник, восхищаясь красотой модели, часто выражал это восхищение с особой чувственностью. И тогда красота наполнялась страстью и уже воздействовала больше своей чувственной, а не Ауховной составАяющей. А^я создания красивого образа, привлекательного внешне, порой не требуется даже 
полного обнажения натуры. Определённое положение рук и тела, некоторые слегка обнажённые его части, плавные минии - всё это может вызывать ощущение красивого и чувственного. Но эта красота нас обделяющая, обманчивая, не Аающая нам узнать главного о ней. В таких работах преобладает так называемое Аионисийское начало, чувственное и страстное. Философ Н.А. Бердяев сказал о такой красоте - «Красота может переходить в свою противоположность, как и всякое начало, оторванное от источника света» (Бердяев, 1993:330). Под светом здесь подразумевается божественное.

Есть в искусстве и такое понятие, как «демоническая красота». Тот же Бердяев пишет, что Аемоническое начало содержится не в красоте и творчестве, а во внутреннем состоянии человека. С этим нельзя не согласиться, ведь творят сами Аюди: и создавая, и воспринимая художественное произведение. В демонической красоте есть свой эстетизм.

Как художник, так и реципиент знают, что такое: симметрия, золотое сечение, перспектива. Такие понятия, как вертикаАь, горизонтаць, хоть непосреАственно и не связаны с категорией красоты, но порождают в нас ассоциации, которые мы соотносим с определёнными смыслами. Эти смыслы закреплены в нашем подсознании. Так, вертикаль (ассоциация верх-низ), связана у нас с представлениями о верхе - как положительном, высоком, а о низе, - как правицо, об отрицательном. Горизонталь (ассоциация мевоеправое) мы связываем с такими смыслами, как: симметрия-ассиметрия, статика-динамика. Горизонталь в картине - это Аиния горизонта, которая заАаёт определённое настроение пейзажу. Ассоциативное пространство у кажАого индивидуально, но детерминировано общими Аля всех условиями физиологии и это тоже необходимо учитывать кажАому художнику, если он хочет быть понятым.

Чувство прекрасного нашло выражение в разных жанрах художественного творчества. В портрете - оно всегда связано не только с внутренним миром портретируемого, но и с отношением к нему художника. Роль художника в Аонесении Ао нас ощущения красоты очень значительна. 3Аесь важны не только школа, мастерство, а сама творческая индивидуальность художника, его Ауховность. Внимательный реципиент всегда сможет отличить красоту от красивости, слащавости. Под видом красоты может подаваться откровенная пошлость. Только богатый Аушевно и духовно художник, сможет сказать о красоте в высшем её понимании.

Аля передачи красоты недостаточно выбрать подходящий сюжет и подобрать соответствующую красивую форму. Важны здесь и такие качества мастера, как искренность и правдивость. Искренность - это мичная заинтересованность изображаемым. Это живое участие в создании художественного образа, связанное с Аичными эмоциями и переживаниями. Подобное отношение всегда подкупает зрителя, заставляет верить в то, что изображено, сопереживать героям произведения. Чувство эмпатии должно быть присуще, как реципиенту, так и художнику.

В качестве примера можно привести произведения Е.Е. Моисеенко. В его картинах часто встречается образ яблони. Он настолько выразителен, что заставляет задуматься о столь явной привязанности художника к нему: яблоня в цвету, яблоня с плодами, ветка яблони и т.А. Наконец, яблоня, как элемент ряда картин, в которых неизменно присутствуют дедушка, мальчик и мошадь (рис. 1). Эта повторяемость не может быть случайной. Скорее всего - это визуализированные воспоминания детства художника, 
очень трепетные, пронизанные светлым чувством. И эта яблоня обретает уже не второстепенный, а глубокий смысл, становится символом - раАости, счастья мирной жизни. Она здесь сродни той черешне на одноимённой картине. Там изображены бойцы, которые в перерыве между боями прилегли отдохнуть на траву и поесть черешни, нарванной в местных садах прямо в фуражку. И эта черешня - уже не еда, это - мечтавоспоминание о прежней мирной жизни, о доме, о близких (рис. 2). И становится понятным, как Арагоценны и прекрасны были эти воспоминания детства Аля Е. Моисеенко, когда он сам был солдатом, и постигац все ужасы войны и плена. Этот пример свидетельствует нам о той радости и красоте, которые были осмыслены и прочувствованы художником и представлены нашему восприятию в виде законченного прекрасного художественного образа.

Искренность, Аюбовь и правдивость (это может быть правдивость чувства) - те Аичные качества мастера, без которых невозможен разговор о художественном произведении как о чём-то прекрасном. Соединение красоты с истиной способствует просветлению бытия.

Мы можем воспринимать как прекрасное и сюжет, в котором присутствуют вечные темы, ассоциирующиеся у нас с понятием красоты. Темы: молодости, материнства, патриотизма, Аетства сразу располагают к себе и отзываются в нас как что-то положительное, близкое, то, что естественным образом входит в нашу эмоциональную жизнь, то, что заложено в нас как красивое - естественное и гармоничное.

Пейзаж - жанр, который немыслим без красоты. И зАесь мы воспринимаем и те виды, которыми художник вАохновиАся, и самого художника, через эмоции, привнесенные им в Аанное произведение. На нас Аействует сама естественная красота этого мира. Она может быть окрашена индивидуальными оттенками, которые сообщил ей художник, но при этом будет узнаваема нами и, как правило, приятна глазу. В реалистической живописи мы будем восторгаться и мастерством художника, и самим прекрасным видом. В импрессионизме - теми ощущениями света и цвета, которые наполняют картину жизнью. Некоторые из нас считают красивыми: неяркие, наполненные тихой грустью, пейзажи И. Аевитана, или какие-то «неприбранные» дворики А. Саврасова, мокрый куг и разбитые Аороги с ясными отражениями синевы небес в огромных цужах на картинах Ф. Васильева, или покосившиеся, утонувшие в снегу старые амбары у И. Грабаря. ТогАа возможно, что восклицание «красиво!» и не сорвется с наших губ, но отзовётся ещё громче - в нашем сознании и в самой душе. Эта красота - в родном, в том, что нам знакомо с детства в нашем ближнем окружении, в книжных илАюстрациях, Аа и в самой художественной митературе. В строках А. Пушкина, С. Есенина, А. Чехова, М. Пришвина, К. Паустовского, в нашем русском фольклоре - всё это воспето и глубоко прочувствовано.

Художник, ощущая эти виды как родные, создаёт художественный образ таким, что переА нами предстаёт само чувство мастера в его визуальном воплощении. Эта художественная работа позволяет слелать обычный виА выАающимся, выразительным. Вся композиция строится таким образом, чтобы подчеркнуть, сопоставить, оттенить главное; заставить все элементы картины служить основному замыслу. И мы вилим в картине И. Грабаря «Зимний вечер» (рис. 3), как великолепен снег, как сопоставАяет художник его красоту, свежесть, чистоту и старое дерево постройки; как умело он 
соединяет и противопоставляет элементы композиции, выводя на первый план всю прелесть зимнего вечера.

Пейзаж всегда служил Аля художников всех эпох объектом Аюбования и вдохновения, но художественное произведение даёт нам необыкновенную возможность: не только полюбоваться красивым видом, но и принять участие в этом мифотворчестве, которое начато было мастером. Символика образа, его наполненность индивилуальным переживанием не выразимым Ао конца, Ааёт реципиенту такую возможность. Раскрывание этого символа, разворачивание в нас обогащает нашу Аушу, нашу индивидуальность, наполняет радостью открытия. Символ в художественном произведении даёт нам то ощущение чего-то непостижимо прекрасного, что становится потом невыразимым содержанием нашей внутренней жизни, его считывание наполняет

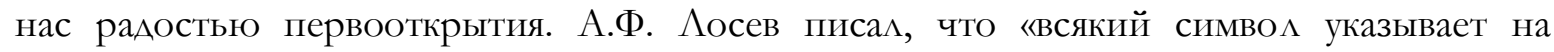
некоторый предмет, выходящий за пределы его непосредственного содержания. Он всегда содержит в себе некоторого рода смысл» (Аосев, 1991:257).

Есть в изобразительном искусстве особый жанр, задача которого - изображать красивое. Это - натюрморт. Мир предметов окружает нас. Но только художник может представить эти предметы в таком состоянии, которое даёт нам полное ощущение красоты. А^я того, чтобы вещи в натюрморте взаимодействова^и, наАо ими залюбоваться самому, найти их пропорциональную и колористическую совместимость, их взаимное Аруг к Аругу расположение. Вещь в натюрморте становится из просто вещи художественным объектом. Та красота, которую обнаружиц в ней художник, становится заметной и Аля зрителя.

Красота растений в натюрморте Аелает его выигрышным, Аюбой растительный натюрморт, как правило, красив (рис. 4). Но как быть, например, с таким произведением как «Натюрморт с вербой» Е. Моисеенко (uлл. 5), можем ми мы сказать о нём, что он красив? Аа. Это красота символа, который никогда не откроется человеку невнимательному, не заинтересованному. Холод зимы за окном. В прозрачном стекле стакана - несколько веток вербы, покрытой скупой зеленью, пробивающихся клейких Аисточков. Всё в натюрморте не ярко, приглушённо, яркие только упругие коричневые веточки, с неумолимой силой противостоящие этому холоАу. Весна близко! В этом ожидании весны, в этом ощущении, заключена главная красота - победа жизни наА холодом вечности. Верба Аля христианского мировоззрения - преддверие Пасхи, Воскресения Христова.

Натюрморт, как и Аюбая живопись, может и Аолжен содержать в себе символ. Поскольку в создании натюрморта используются обычные предметы, то это значит, что Аля художника - это не просто предметы, а носители смыслов. ИногАа тот, или иной предмет появляется в работах мастера довольно часто. У К. Петрова-Водкина, например, это яблоки, которые представлены в картине, как нечто самодостаточное, совершенное. Натюрморт «Яблоки» - это пять яблок на красном фоне, словно рассыпанных в неопределённом порядке (рис. ๑). Замечательна ткань, на которой они изображены, она вся в изломах, словно какой-то фантастический пейзаж. Яблоки здесь - главное, вполне самодостаточное и совершенное. От них почти нет теней, они словно парят наА этой сияющей внутренним светом «пустыней». В этом произведении есть что-то космическое. 
Если взять Аля сравнения работу И. Грабаря «Яблоки» (рис. 7), то мы сразу заметим, как велика межАу ними разница, хотя оба они по-своему красивы.

В натюрморте красота - это и красота самих предметов, созданных человеком. 3Аесь художник даёт нам возможность разглядеть в обыденном нашем окружении красоту простого, утилитарного. Это красота формы, которая возникла не случайно, а как осмысленная, целесообразная, проверенная временем. В народном искусстве мы можем наблюдать эту красоту и в материале. Каждый природный материал имеет свою естественную красоту - фактуру. Настоящий умелец умеет находить Аля неё нужную форму. Фактура - это не только поверхность того или иного материала, это наше к ней отношение. Фактура воздействует на наше сознание как архетип. Мы можем не задумываясь воспринимать поверхность дерева, керамики, камня и Аругих природных материалов, из которых изготовлено то, или иное изделие. Более того, мы можем ощущать её, Ааже в виде художественного изображёния, как, например, в натюрмортах В. Стожарова (рис. 8). У нас есть предрасположенность к тем, или иным природным материалам. КажАая такая фактура имеет свой неповторимый рисунок, цвет, которые могут быть задействованы художником при изготовлении изделия. И в этой эстетике заложена живительная сила природы. Эта красота естественная и простая. Простота в искусстве выступает как правдивость, как противопоставление манерности и фальши.

\section{Эмпатия как постижение прекрасного}

Настоящая красота никогда не откроется реципиенту как духовное содержание, если не произойдёт эмпатии, или вчувствования. Это некий процесс оАушевления художественного произведения. Эмпатия - субъективный процесс, в этом и есть психологическая её составцяющая. Она всегда связана с выразительностью художественной формы. В процессе эмпатии художественное содержание становится частью воспринимающего, переживающего субъекта.

В русской философии, в частности, у С. Франка, мы находим возражение против эмпатии, как процесса, в результате которого мы вживаемся в художественную реальность и передаём ей часть своих чувств. Он утвержАал, что «человеческий дух находит в эстетическом опыте «готовым», непосредственно Аанным в составе самой реальности черту выразительности, в которой ему непосредственно открывается внутренняя значительность, осмысленность, Аушеподобность реальности» (Франк, 1991:429). Человек может открыть себя этой реальности. Существует «сродство» межАу интимным миром человеческой Аушевности и основой того, что предстоит нам как внешний предметный мир. Красота представ яялась мыслителю, как отблеск рая на земле, и непостижима в земном нашем существовании в полноте своей. Подобный взгляд на красоту, как понятие, в сущности своей, метафизическое, был присущ многим мыслителям XIX-XX веков. Как бы то ни было, но «эмпатия» сегодня - общепризнанная способность человека и отрицать её существование мы не можем. Скорее всего, она распространяется на ту часть нашего сознания, которая связана с нашими чувствами, и не только, поскольку чувственная жизнь вАияет на нашу Ауховность.

Объяснить воздействие на человека художественной реальности сейчас уже могут не только представители гуманитарной науки. Пытаются понять феномен эмпатии и 
учёные-физиологи. Нейробиолог Семур Зеки ввел термин «нейроэстетика». Благодаря исследователям человеческого мозга, мы имеем представление о том, как процесс художественного восприятия осуществляется на физиологическом уровне. Профессор МГУ В. Аубынин в своей видео-лекции «Мозг: общие принципы нейроэстетики» объясняет процесс эмпатии с точки зрения биологической врождённости у нас знания о красоте. Он выделяет 4 пункта, связанные с нашими физиологическими способностями, которые делают Аля нас произведение искусства прекрасным. Учёный представляет этот процесс как биологическую потребность человека и его мозга.

Сейчас немало учёных в области нейрофизиологии пытаются разгадать тайны человеческого мозга, который так же бесконечно загадочен, как космос. Наука ищет объяснений всему, что окружает нас в мире и тому, как устроен сам человек. Эмпирическое знание всегда считалось убедительным. Аа, современные Аостижения учёных-исследователей мозга, открывают нам невообразимые его возможности. И все эти исследования оказались настолько серьёзными, что мы уже имеем помимо человеческого, искусственный интелмект. И всё-таки напрашивается простой и одновременно закономерный вопрос - «зачем?». Наверное, есть смысл поведать миру о том, где находятся те, или иные центры наших ощущений, использовать эти знания в медицине. Но, в целом, чувство прекрасного, о котором здесь илёт речь, не может находиться в каком-то определённом участке головного мозга, так как, - это чувство целостного в человеке. У А.Ф. Аосева можно прочитать такие строки: «Если же мы возьмём красивый букет цветов, то, рассматривая его, мы затратим вероятно, десятки, если не сотни, разного рода осмысленных актов сознания. И тем не менее букет цветов есть именно букет цветов, а не что-то иное; и чтобы понять его именно как букет цветов, мы должны затратить единый и нераздельный смысловой акт, который отнюдь не Аелится на акты восприятия отАельных составляющих его цветов и уж тем более отАельных свойств кажАого цветка». (Аосев, 1991:267). Так и в самом акте восприятия прекрасного невозможно определить какая часть коры головного мозга отвечает за столь сложный процесс. Более того, мы имеем Аостаточно примеров, когда мозг может полностью противиться тому, что нам говорят наши чувства о каком-то прекрасном объекте.

Святитель Аука Войно-Ясенецкий - врач и учёный, писац «пока мы имеем сделать только оАно, но чрезвычайно важное заключение: кроме обычных раздражений, адекватных нашим органам чувств, наш мозг и сердце могут воспринимать гораздо более важные раздражения, исходящие из мозга и сердца других Аюдей, животных и всей окружающей нас природы и, что важнее всего, из неведомого нам трансцендентального мира» (Войно-Ясенецкий, 2005:40). Человек не изолированное существо, он находится в таинственной и нерасторжимой связи со всем этим. И эта связь понимается учёным как Ауховная энергия Аюбви, которая всё животворит. Красота в мире и есть одно из проявлений этой животворящей энергии. Чувство красоты в человеке взаимосвязано с красотой всего мироздания, и конечно, всего человечества в целом. ИндивиАуальное и всеобщее в красоте и дают ту полноту и гармонию, которой ищет каждый из нас. «Мы в каком-то смысле «общаемся» с прекрасным - с красотой кандшафта или прекрасного мица, с картиной, статуей, собором, музыкальным произведением, - как мы общаемся с Аругом, с близким; мы усматриваем во внешней реальности что-то сродное нашей 
интимной глубине, нашему потаённому самобытию; и в момент эстетического наслаждения мы перестаём чувствовать себя одинокими, а, напротив, находим в окружающей нас реаАьности некую исконную «родину» ААя нашей «Ауши», этой одинокой скиталицы в преАметном мире» (Франк, 1990:428).

\section{Закиючение}

Вся история искусства - это, история познания красоты. Она - основа Аюбого искусства. Не ощущая красоты, невозможно в полной мере понять художественное произведение как некую целостность. То, что мы видим, как отдельные элементы и как композицию в целом - недостаточно, Аля полноты восприятия. Это первая ступень. Через видимое приходит к человеку знание о мире. Но это знание не будет полным, если оно

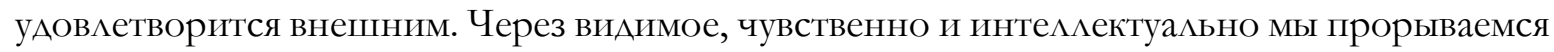
к внутреннему, глубинному в произведении. Красота художественного произведения это представленный нам внешне, эстетически оформленный объект, который получает свою завершённость и полноту в нашем Я - активном, чувствующем, мыслящем, ищущем этой красоты как внутреннего содержания.

Искусство имеет бесконечный потенциал воздействия на человека, так как оно связано с нашей чувствительностью, так как оно и предназначено Аля того, чтобы эту чувствительность услаждать. Знание о красоте содержится в нас как сознательное и бессознательное. Вся история человеческой культуры, начиная с Аревних времён, повествует нам о том, что такое красота. Всё зависит от творческой индивиАуальности, как художника, так и реципиента, от того, что каждый конкретно хочет получить от искусства. Есть индивидуальный вкус, желание узнавать новое, предпочтения в выборе жанров и видов, и, наконец, возможности. Можно, благодаря общению с искусством, просто разнообразить свою жизнь, впустив в неё немного красоты и гармонии. Но можно, благодаря искусству, раскрывать такие Аали Аушевного и Ауховного пространства, что это станет Аля нас настоящим Аичностным приобретением. Чем богаче становится Аичность, тем богаче и ярче ей открывается мир, как в его Аанности, так и в его трансцендентности.

\section{Список источников информации:}

Басин, Е.Я., Крутоус, В.Б. (2016). Психология искусства. Аичностный подход. Москва: Юрайт.

Бердяев, Н.А. (1993). О назначении человека. Москва: Республика.

Вейль, Г. (1968). Симметрия. Перевод с английского Б.В. Бирюкова и Ю.А. Аанилова. Москва: Наука.

Аосев, А.Ф. (1991). Философия. Мифология. Культура. Москва: Политиздат.

Аука свт. (Войно-Ясенецкий) (2005). Аух, Ауша и тело. КАин: Христианская жизнь.

Нисский, Г. (1995). Об устроении человека. Санкт-Петербург: АХІОМА.

Соловьёв, В.С. (1991). Философия искусства и митературная критика. Москва: Искусство.

Франк, С. (1990). Сочинения. Москва.

Хёйзинга, Й. (1988). Осень Средневековья. Москва. 
Эко, У. (2017). Искусство и красота в средневековой эстетике. Москва: ACT: CORPUS.

\section{Приможения}

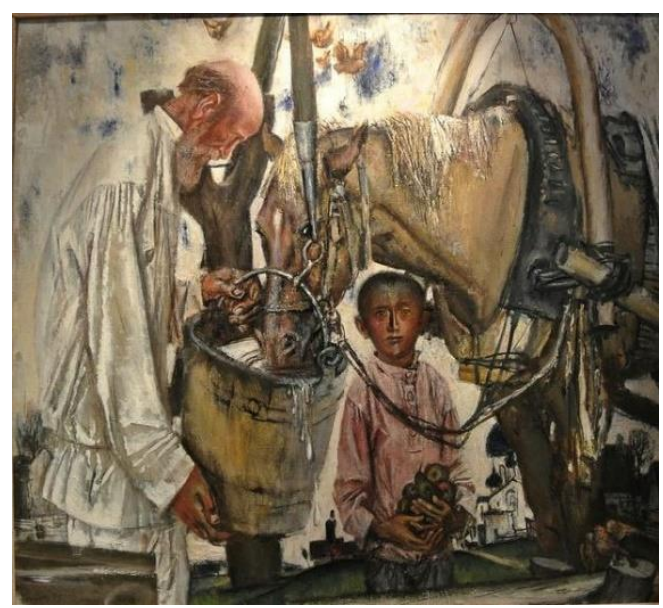

Рисунок 1. Моисеенко Е.Е. «У КОАОАЦа〉

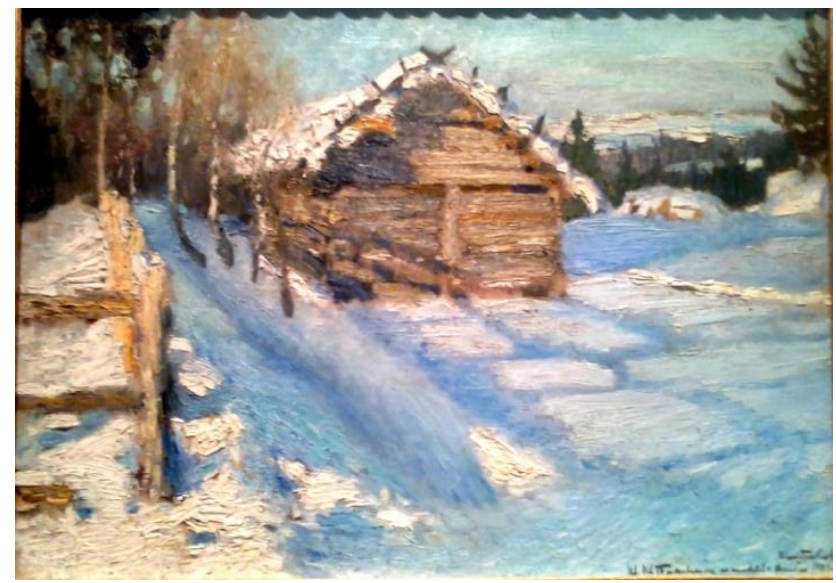

Рисунок 3. Грабарь И.Э. «Зимний вечер»

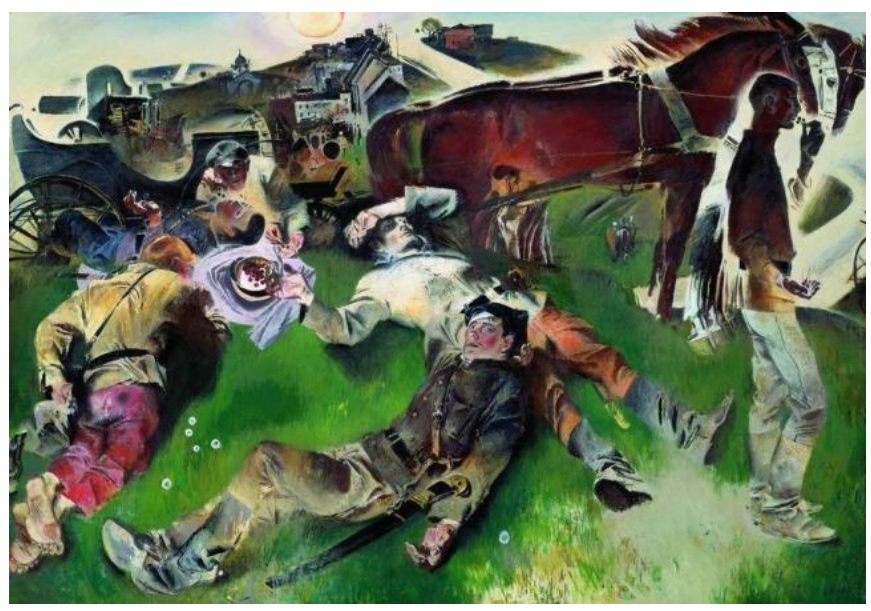

Рисунок 2. Моисеенко Е.Е. «Черешня»

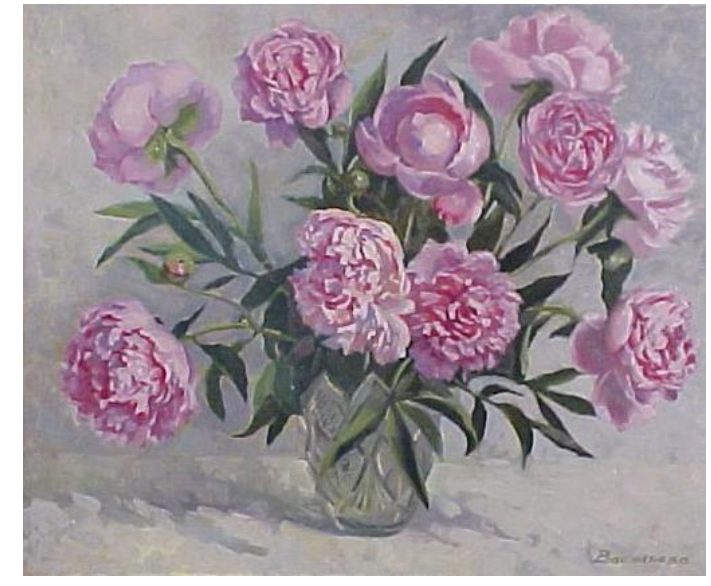

Рисунок 4. Васильева Е.И. «Пионы в вазе» 


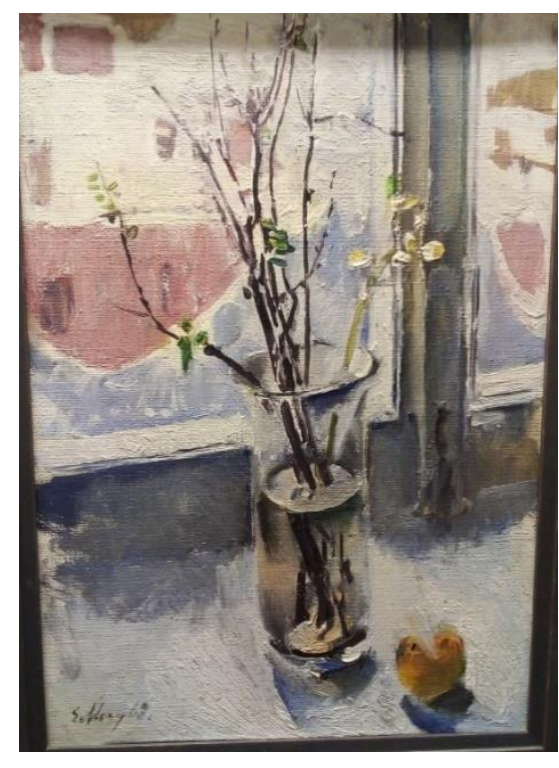

Рисунок 5. Моисеенко Е.Е. «Натюрморт с вербой»

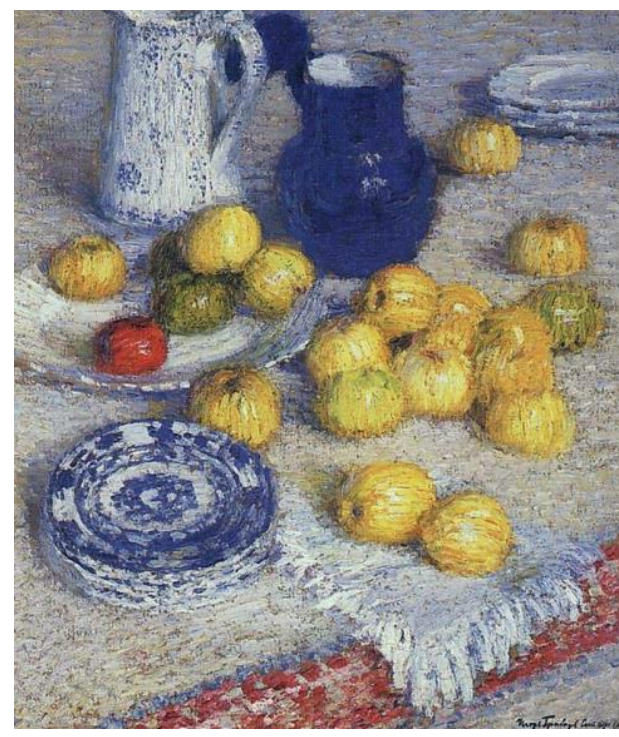

Рисунок 7. Грабарь И.Э. «Яблоки»

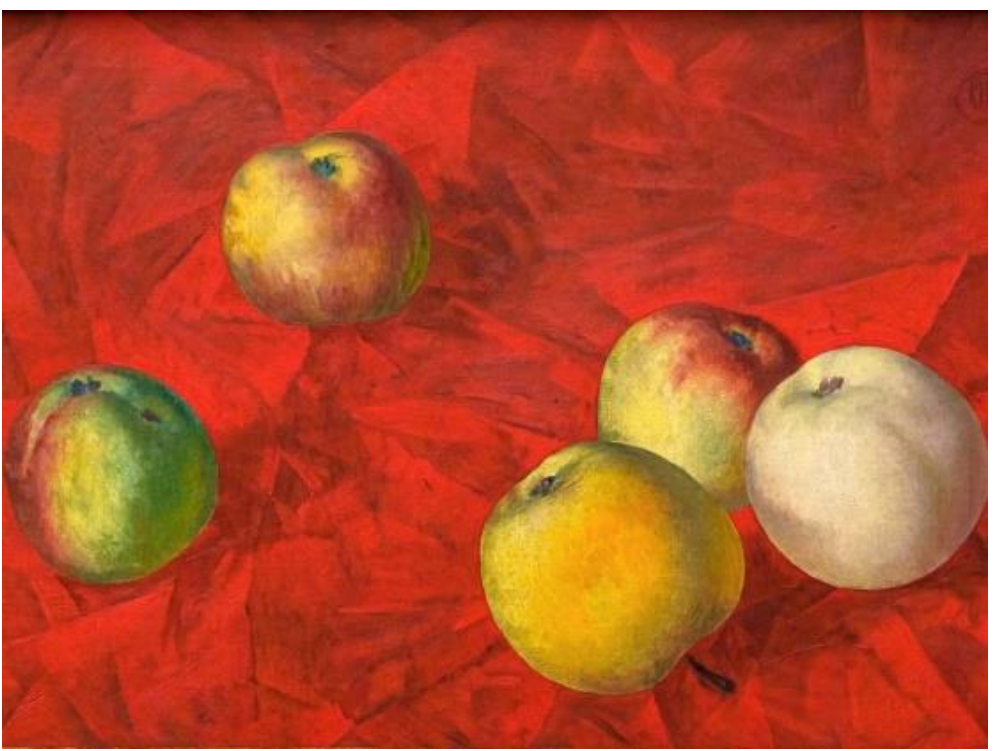

Рисунок 6. Петров-Водкин К.С. «Яблоки»

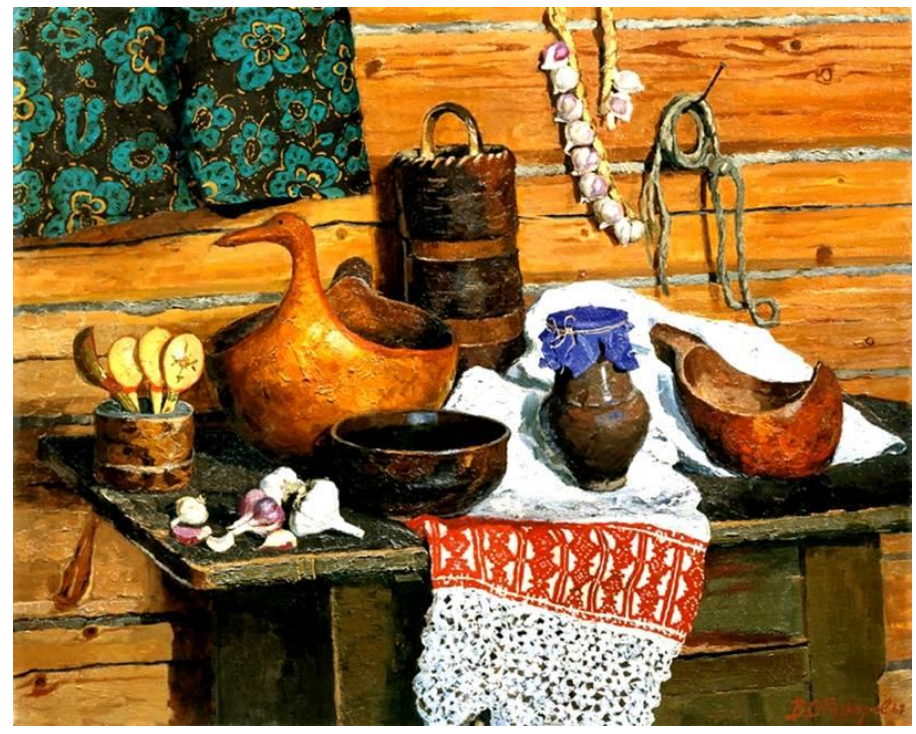

Рисунок 8. Стожаров В. «Братина и чеснок» 
